\title{
Effects of scaffolded intensive reading on students' reading comprehension performance
}

El impacto de la lectura intensiva en andamiaje sobre la comprensión lectora de los estudiantes

\author{
Volumen 17, Número 1 \\ Enero-Abril \\ pp. 1-29
}

Henry Sevilla Morales

Revista indizada en REDALYC, $\underline{\text { SCIELO }}$

Revista distribuida en las bases de datos:

\section{LATINDEX, DOAJ, REDIB, IRESIE, CLASE, DIALNET, SHERPA/ROMEO, QUALIS-CAPES, MIAR}

Revista registrada en los directorios:

ULRICH'S, REDIE, RINACE, OEI, MAESTROTECA, PREAL, CLACSO 


\title{
Effects of scaffolded intensive reading on students' reading comprehension performance \\ El impacto de la lectura intensiva en andamiaje sobre la comprensión lectora de los estudiantes
}

\author{
Henry Sevilla Morales ${ }^{1}$
}

\begin{abstract}
This research sought to explore the connection between a small-group intensive reading comprehension project and students' performance in two sample English national exit exams (ENEEs) developed by the Ministry of Public Education, Costa Rica. The data were gathered from an intervention plan that combined the theoretical principles of schema theory, scaffolded reading comprehension, and intensive reading. The study adopts an action-research approach and uses a mixed design that combines quantitative and qualitative data in the analysis and interpretation of results. Participants included twelve students from a public high school in the Western Area of Costa Rica who needed special preparation for the ENEE, which narrows the research scope down to this population only. The data collection techniques included two sample ENEEs, field notes, and research artifacts. Findings reveal positive effects of scaffolded reading comprehension on student ENEE performance, but also they warn that generalizations to larger populations are not possible. The study yields implications at theoretical and practical levels, and it calls for further investigation as a way to tackle the limitations identified.
\end{abstract}

Keywords: educational strategies, scaffolded reading, intensive reading, English national exam.

Resumen: El presente artículo buscó estudiar la relación entre un proyecto de lectura intensiva en inglés a menor escala y el desempeño de los estudiantes al resolver dos exámenes correspondientes a las pruebas estandarizadas de bachillerato del Ministerio de Educación Pública, Costa Rica. Se recabaron datos a partir de un plan de intervención que conjugó los postulados teóricos de la teoría del esquema, la lectura en andamiaje y la lectura intensiva. Se hace un abordaje de investigación-acción mediante un diseño mixto que utiliza fuentes cuantitativas y cualitativas en el análisis e interpretación de los datos. Los sujetos fueron doce estudiantes de un colegio público de la Dirección Regional de Educación de Occidente de Costa Rica, quienes requerían preparación adicional para dichas pruebas. Esto delimita los alcances del estudio a esta población únicamente. Las técnicas de recolección de datos incluyen dos exámenes de bachillerato, notas de campo e instrumentos de investigación. Se concluye que la lectura en andamiaje tiene un impacto positivo en la comprensión lectora de los estudiantes en exámenes de bachillerato, pero también se advierte que los resultados no pueden ser generalizados a otras poblaciones. De igual forma, la investigación plantea implicaciones a nivel de teoría y práctica, y sugiere futuros estudios sobre el tema a fin de abordar las limitaciones referidas.

Palabras clave: estrategias educativas, lectura en andamiaje, lectura intensiva, prueba nacional de inglés.

\footnotetext{
1 Profesor de la Escuela de Literatura y Ciencias del Lenguaje de la Universidad Nacional, Costa Rica, y de la Carrera de Bachillerato y Licenciatura en la Enseñanza del Inglés de la Universidad de Costa Rica, Sede de Occidente. Máster en Segundas Lenguas y Culturas.
}

Dirección electrónica: henrysevilla@gmail.com

Artículo recibido: $1^{\circ}$ de marzo, 2016

Enviado a corrección: 27 de julio, 2016

Aprobado: 21 de noviembre, 2016 


\section{Introduction}

Today more than ever in the history of language education, we are compelled to accept the fact that reading comprehension skills in English are no longer a luxury. The increased dissemination of English-based research, the formal study of engineering and computer science disciplines, the need to access content-specific tutorials or seminars online, and even seemingly trivial activities such as playing your favorite video game or understanding directions in a travel guide are a few of the many examples that come to mind when one thinks about English reading literacy today.

As a response to this reality, many language instruction programs have placed reading comprehension at the forefront of their curricula; and research has emerged that calls for a shift in the way we view and teach for this component (Alyousef, 2005). Some scholars such as Grabe (1991) and Carrel (1989) rank reading comprehension as "one of the most important skills in academic and professional success in general, and in second and foreign language education in particular" (as cited in Attarzadeh, 2011, p. 5); and yet others have more sharply taken on the position that reading comprehension should be "a pre-requisite to almost all graduate programs" (Alderson, 1984, as cited in Attarzadeh, 2011, p. 5). For Costa Rica's Ministry of Public Education (henceforth, MEP, by its initials in Spanish), ability to comprehend written texts is crucial in order to meet the overall purpose for English language teaching in our national context: "to give students a tool to directly access scientific, technological and humanistic information and, in this way expand their knowledge of the world" (2014, p. 14), as well as to allow them to fulfill personal needs and interests that may go from wanting to comprehend the written message of their favorite lyrics in English to engaging in intellectual practices such as reading literature classics (MEP, 2014).

For many in the general academic and scientific community, reading in English is also essential as a way to access technical information on their subject areas, and as a means of increasing their acquaintance with related fields wherefrom they extrapolate practical knowledge. But while there is general consensus on the importance of effective reading comprehension skills in English, recent authors such as Rhea and Baenen (2007), Novotny (2011), Attarzadeh (2011), Choo, Eng, and Ahmad (2011), and Ebrahimi and Rahimi (2013) have highlighted that many foreign and second language learners lack appropriate reading skills to cope with the demands of their academic and future work settings.

In the context of Costa Rica's public education, senior students at secondary school level are required to take an English national exit exam (henceforth, ENEE), where their 
language proficiency level is tested. While the exam focuses only on reading comprehension and does not test higher-order skills, many students fail to pass it due to inappropriate training in reading comprehension skills (Coon, Ferrel and Klott, 2014). Since the test is a graduation requirement, failure to pass it most likely results in low student achievement rates, alternative decision-making and remedial plans, institutional distress, and negative teacher reinforcement as English teachers are often blamed for the students' low performance.

In this paper, I report on the findings of a small-scale research project conducted at a public high school in the Western Area of the MEP, in the Central Valley of Costa Rica. The project sought to solve a number of classroom problems that intensified with the 2014 monthlong teachers' national strike, an event that would lead curricular authorities to modify their school calendars and to cut down on the amount of topics to be studied. Given this state of affairs, intervention was urgent as many of the senior students needed intensive preparation for the ENEE, and even more so considering their low proficiency levels and the delays brought about by the strike.

The goal of this paper, thus, is to discuss the connection between a small-scale intensive reading comprehension project and students' performance on two sample English national exit exams. Framed within the philosophy and logistics of action research, the study endorsed a mixed methods approach in the analysis and interpretation of data. Findings yield implications for both theory and practice at three different levels. First, they enlarge the body of empirical studies on intensive reading and test performance; second, they assist our understanding of how reading comprehension can be enhanced through small-scale action plans; and third, they add up to the list of action research conducted in Costa Rica that help break away from the traditional teacher-researcher dichotomy (e.g., Acuña and Campos, 2015; Bula, 2010; Bula, 2015; Díaz-Ducca, 2015; Roberts, 1999; and Sevilla and Gamboa, 2015). Broadly speaking, while each of these studies deal with issues different from the one being addressed in the current paper, they share a common trait: They are investigations conducted by actual teachers in their own teaching contexts. This is particularly significant because one of the core premises in action research is to demystify the long-since held idea that teaching and research were two different (if not polar) choices ${ }^{2}$.

All in all, the study affords an alternative to tackle the teaching of reading comprehension skills in public secondary schools, as it calls for reflection on teaching

\footnotetext{
${ }^{2}$ For expansion on this, see: La investigación-acción: Conocer y cambiar la práctica educativa, by Antonio Latorre (included in the "References" section of this paper).
} 
practices that may best help us attain the language objectives of our national education system.

\section{Literature Review}

\subsection{Historical Overview}

Historically, reading comprehension has been a central skill in most language programs. In the grammar translation times, for example, reading skills were pursued as a way to study the classics of literature in their original language (Zainuddin, Yahya, MoralesJones and Ariza, 2011). "The main goal for learning [a language] was not for speaking and/or communicating", but rather to be able to read literary masterpieces in Greek and Latin because that was a desired skill expected from aristocracy and elite groups of the epoch (Zainuddin et al., 2011, p. 64). Today changes in the global economy and the geo-political landscape posit unprecedented challenges in the educational arena which put reading comprehension at the frontline of policy making and curricular planning.

In our national context, the relation between reading comprehension and the establishment of national tests can be traced back to the decade of the 1980s, during and after Oscar Arias' administration. According to Otárola and Valverde (2013), in those years, our education system experienced several adjustments such as "the decline in student performance, dropout increase and the shortage of qualified teachers [which] was extremely worrying" (p. 20). The authors explain that "the government [thus] launched various educational reforms, such as the national testing system $\left(6^{\text {th }}, 9^{\text {th }}\right.$ and $11^{\text {th }}$ grades $)$, and the introduction of computer literacy in the classroom, among others" (p. 20). In 1988, with the reestablishment of the national tests-or national exit exams-, the MEP proposes changes in classroom methodologies along the lines of literacy practices so that reading comprehension skills were enhanced and that the ENEE were passed (Córdoba, Coto, and Ramírez, 2005). From there on, reading comprehension became not only a desired skill in secondary education but also a compelling element to work on since it is the only skill that is measured by the national English authorities.

According to the current English Syllabus for Diversified Education, English teachers must teach and assess the four macro skills of the language (i.e., listening, speaking, reading, and writing). However, to date there seem to be practical, logistics, and/or budgetary reasons in relation to why the ENEE assesses only reading comprehension at the end of the diversified cycle. 
In an attempt to put together the action plan described in the introduction of this paper, I profited from the theoretical underpinnings of schema theory and scaffolded reading comprehension, as well as from the foundations of intensive reading, which are discussed below.

\subsection{On Schema Theory and Scaffolded Reading Comprehension}

According to schema theory, reading comprehension entails an interaction between the reader's background knowledge and the text while the reading activity takes place; a view that has also been shared by cognitive constructivists with regard to how comprehension and learning in general work (see Derry, 1996). In the words of Harris and Hodges, constructivists, comprehension is "the construction of the meaning of a written or spoken communication through reciprocal, holistic interchange of ideas between the interpreter and the message in a particular communicative context" (as cited in McLaughlin and Overturf, 2013, p. 55). Smith (1994), along the same lines, believes that

[...] everything we know and believe is organized in a theory of what the world is like, a theory that is the basis of all our perceptions and understanding of the world, the root of all learning, the source of hopes and fears, motive and expectancies, reasoning and creativity. (p. 8, as cited in Shen, 2008, p. 105)

As evident from this quotation, Smith's view on learning is a comprehensive one, which acknowledges the context-bound nature of all knowledge. It breaks away from the traditional, Cartesian-rationalist idea that reality is objective and welcomes subjectivity.

This new view, Shen argues, is "our shield against bewilderment" (2008, p. 105). In the educational context, schema theory contributes to our understanding of reading as an interactive process where incoming data are processed in the brain by means of interaction with previously existing knowledge called background knowledge, and not just as a passive activity where information is deposited into the reader's mind. In schema theory, what the reader brings to the reading experience in the form of background knowledge is valued and honored: "A text only provides directions for [...] readers as how they should retrieve or construct meaning of their own, namely acquired knowledge" (Shen, 2008, p. 104). This standpoint is also supported by Erten and Razi (2009), as well as by many other scholars such as Bartlett (1932, as cited in Erten and Razi, 2009, p. 61) or Carrrel and Eisterhold (1983, as cited in Erten and Razi, 2009, p. 61) who, even before the heyday of the 
communicative approaches to language instruction, had already acknowledged the place for background knowledge in the reading comprehension process.

Along with these discussions, Stein and Trabasso (as cited in Willis, 2014) list elements of reading comprehension commonly used by teachers, such as finding the main idea in a narrative, detecting cause-effect relationships among events, ordering narrative events in the correct temporal sequence, use the information to make judgments about the text, and, ultimately, paraphrasing or summarizing. According to Stein and Trabasso, the following are essential principles in the cosmology of schema theory:

- Schema is thought to guide encoding, organization and retrieval of information.

- Schematic knowledge has been shown to have a significant effect on organization of ambiguous or disorganized stories.

- Schemata are assumed to guide the reader in constructing hypotheses about what kind of information should occur in the text and the logical connections between the events (as cited in Willis, 2014, pp. 236-237)

McLaughlin and Overturf (2013) assert that in reading, comprehension is reflected in schema-based learning development, which supports the idea that learning takes place when new information is integrated with what is already known. In other words, the more a learner knows about a given topic, the easier it is for them to make connections between what they know and what they are learning. Certainly, other perspectives to this may exist, but they are for now outside the scope of this paper.

Closely intertwined with schema theory, the notion of scaffolded teaching-learning became central in the completion of this research. The core idea behind scaffolded learning is basically that the learner can and will only have access to knowledge that is within what Vygotsky referred to as the Zone of Proximal Development (ZPD). In other words, in order for learning to take place, the learner must be taught only what is achievable at his stage of cognitive development. According to Attarzadeh, research has suggested that scaffolding is a "mediating strategy which must be both leveled for the learner's apparent ZPD and helpful" in overcoming the procedural problems already displayed by the learner along the course of the educational experience (2011, p. 5). Henceforth, in order for effective reading comprehension to take place, it is necessary to set up the pedagogical conditions that: a) allow the learner to relate newly-incoming data to existing background knowledge he already possesses and $b$ ) guarantee that all incoming data are within the learners' ZPD by means of scaffolded pre- 
reading activities that, altogether, help the students bridge the gaps between the new and the soon-to-be learned data.

\subsection{Stages in Intensive Reading}

In order to run the action research project, it became necessary to harmonize the principles of schema theory with those of scaffolded reading comprehension into a procedure of pre-, while-, and post-reading activities. According to Alyousef (2005), in the pre-reading stage, schema activation takes place by means of helping the students become aware of the background knowledge they already have built in. In the while-reading stage, transaction with the text occurs by means of reading strategies such as building mind maps, summarizing, getting the gist, scanning, skimming, and others. Alyousef claims that while-reading activities have proven successful because they enable the reader to "tackle the text by developing their linguistic and schematic knowledge" (2005, p. 150). He also notes that recent research has highlighted the importance of explicit while-reading activities because they allow for the conjunction of top-down and bottom-up processing activities in the reading comprehension event. The Trinity Western University Counseling Center (n.d.) explains that these whilereading strategies can be concretely incorporated in the form of explicit questions, purposeful reading, summarizing, and testing oneself by rereading the material to make sure effective comprehension took place (pp. 2-3). The last stage is the post-reading stage. In this stage, teachers should take the time to reflect upon the reading experience and to wrap up the lesson through classroom activities such as matching exercises, close exercises, and/or "cutup sentences and comprehension questions" (Alyousef, 2005, p. 150). The idea behind this last stage is to make sure that actual reading comprehension has taken place and that students have a chance to reflect upon their learning process.

While I am aware that the list of models and paradigms to address reading comprehension in the language classroom is extensive, I decided to profit from the ones reviewed above given the specifics of the context being dealt with. For a comprehensive examination of such models and paradigms, see the 2002 paper by Patricia L. Anders: Toward an Understanding of the Development of Reading Comprehension Instruction Across the Grade Levels. With this in mind, let us now briefly examine the thematic and contextual makeup of the ENEE. 


\subsection{The English National Exit Exam (ENEE)}

The ENEE is a graduation requisite test that "all high school seniors $\left(11^{\text {th }}\right.$ grade for liceo and liceo académico, or $12^{\text {th }}$ for colegio técnico) must pass [...] in order to graduate from high school" (Coon et al., 2014, p. 2). This test makes up 60\% of the student's final mark, while the other $40 \%$ is made up of the total Grade Point Average (GPA) obtained by averaging out the annual grades earned in all the academic subjects during the last two or three years $\left(10^{\text {th }}\right.$ and $11^{\text {th }}$ for academic high schools and $10^{\text {th }}, 11^{\text {th }}$, and $12^{\text {th }}$ for technical high schools). The test focuses exclusively on reading comprehension and is based on 14 themes covering a wide range of sub-themes and contexts.

During the administration of the test, students are given two hours and thirty minutes to complete a total of 70 multiple choice questions based on 17 texts about any of the 14 themes mentioned above. Each text is followed by two to six reading comprehension questions that may vary in degree of complexity and type of reading skill required. According to Coon et al., $(2014$, p. 2), important reading comprehension skills in this test include: "deducing meaning from context, finding key words, focusing in general meaning, and understanding how modal verbs change a sentence's meaning". Extrinsically, students are expected to make use of other intensive reading skills such as summarizing, reading for the gist, skimming, scanning, making inferences, and so on, in order to arrive at the correct answer in each test item.

As I have stated in the introduction of this paper, while this test may not assess complex, high-order thinking skills, it usually represents a challenge for both students and teachers if adequate preparation is not ensured. In the case of the 2014 academic year, the national strike brought about changes in the curricular agendas of most academic and technical secondary school institutions, including the high school where this research took place. The section that follows outlines the methodological procedures used for the collection, analysis and interpretation of the results obtained upon conducting this action research.

\section{Methodology}

\subsection{Research Approach}

This is an action research that stems as an initiative to assist eleventh grade students of a public high school of the Western Area of Costa Rica in improving their performance in the ENEE. While the research design combines features of qualitative and quantitative techniques (QUAN-Qual model) in the analysis and interpretation of the data, it is best 
conceived as action research in nature, with a prevalence of quantitative analysis because of the nature of the data collected. In the view of Richards and Lockhart (1994, p. 12) state, action research attempts to increase teacher's understanding of a phenomenon in their teaching contexts so as to bring about chance in classroom practices. The authors go on to state that action research consists of several phases that often include: planning, action, observation, and reflection, with high chances that the research cycle may start again in order to arrive at stronger conclusions on the phenomenon under study. All in all, the study affords Latorre's (2014) as well as Efron and Ravid's (2013) view of action research as an umbrella term to describe any type of research that seeks to come across everyday solutions to classroom pedagogy. A more detailed description of the phases followed within the present study will be provided in the procedures section of the methodology.

\subsection{My Motivations to Run the Action Research Plan}

In February 2014, I was appointed to teach a 28-student eleventh grade group in a public academic high school of the MEP's Western Area, in the Central Valley of Costa Rica. There I was confronted with the following limitations: Firstly, the majority of the students lacked basic reading skills to cope with the demands of the ENEE. They did not have the vocabulary, syntactic, semantic or overall procedural knowledge to guide them into completing simple in-class reading comprehension tasks. In addition to this, I was faced with a culture of reluctance toward English on the part of these students.

The second problem had to do with loss of classes during the whole academic year. This was so because of a number of reasons: a) Initially, I was appointed to teach this class only temporarily because the official English teacher was supposed to come back from medical leave at some point at the end of March. But her medical problem worsened so I was reappointed to fill in for her until the end of June. At the beginning of May, a one-month-long strike was called for by the national teachers' unions (SEC, APSE, and ANDE) due to payment delays and debts with thousands of MEP teachers (Font, 2014). Striking teachers resumed classes at the beginning of June and, as a remedial plan to keep up with the academic calendar, some institutional authorities decided that some topics and objectives were cut down on in order to finish off with the themes in the yearly-plan as established by the MEP.

Along with these problems, there were also problems with further interrupted appointments because the official teacher came back to teach the group for two weeks before 
vacations in June and went on sick leave again after vacations in the middle of July. To make matters more complicated, independence celebrations and other civic activities held during September took over many of the few English classes that were left because, unlike other grades, eleventh graders finish their institutional calendar at the end of October in order to be able to prepare for the ENEE. Lastly, things got more complicated because, besides preparing these students for the English ENEE, I had to work on the development of the other macro skills as stated in the English Syllabus for Diversified Education (MEP, 2014, pp. 2122).

In order to cope with these many problems, I set up an action research project which consisted of reinforcement classes during five weeks prior to the ENEE. The plan involved two-hour intensive reading comprehension sessions arranged twice a week where reading tasks were designed using the principles of intensive reading, schema theory, and scaffolded teaching-learning principles derived from Vygotsky' Zone of Proximal Development (ZPD) postulates. In the collection, analysis and interpretation of the data, I made use of: 1) artifacts such as classwork annotations on students' behaviors and attitudes towards the English subject, 2) classroom field notes on students' performance during the different reading stages (see appendix 1), 3) and two sample ENEEs administered in the middle and at the end of the treatment.

\subsection{Participants and Context of the Study}

Participants in this study included 12 eleventh grade students, ages 17 to 19 years old (7 females and 5 males) who were about to take the ENEE and who had shown low (59 and below) and somewhat low (between 60 and 69) achievement in the regular English classes throughout the year 2014. The students attended a rural high school in the Western Area of Costa Rica's Ministry of Public Education and came from different socio-economical backgrounds. During the time the research was conducted, they had finished regular high school classes and attended reinforcement classes (or centros, as they call them in high schools) in the different subjects which are tested in their respective National Exit Exams. In this way, besides the other subjects, they attended English reinforcement classes twice a week, three 40-minute lessons each time. 


\subsection{Procedure}

The procedures for the conduction of this action research included an initial reflection, planning, observation, and action. The first phase, the initial reflection, included three aspects: a) A great share of the students performed poorly in my tests throughout the year; b) many classes were missed during throughout the year because of the factors described previously in this paper; and c) the textbook used had an integrated-skills orientation that demanded for the completion of many components, besides reading comprehension. So, the second stage was the selection of an action plan that would respond to the needs identified in the initial reflection. Upon devising the action plan, the model was run and observation was carried out (third stage) during the five-week duration of the plan. Throughout these five weeks, ten two-hour classes took place. A reflection of the action plan was conducted thereafter, which became the data for the study, which I will analyze in section IV in this paper.

Before we delve into the data analysis, however, it is important to frame an idea of the teaching procedures that resulted from the combination of schema theory, scaffolded reading comprehension, and the principles of intensive reading adopted during the running of this research.

\subsubsection{Scaffolding Reading Comprehension}

In order to supply reading comprehension practice that resembled reading exercises the students would find in the ENEE, I used a textbook called English Made Easy: Bachillerato, written by Jimmy Ramírez Acosta, and published by Grupo Dinatext, because the book complies thoroughly with the topics, level of difficulty, vocabulary and format of the ENEE. However, because of the students' proficiency level, I decided to scaffold their background knowledge with vocabulary and structures that they would find in the texts.

The book is arranged into four main sections: reading comprehension exercises, vocabulary, grammar structures, and a final test that resembles the test they were going to face when they would take the actual ENEE. Because the sections are presented separately along the book, I decided to bridge schema theory and scaffolded reading comprehension by having the students do the vocabulary exercises before they read each of the texts of the reading comprehension exercises section. Additionally, I brought pre-reading activities such as crossword puzzles or word search exercises to help them better process the newly incoming data. I also made sure to create a sense of connection between their background 
knowledge, what students were about to learn, and what remained to be learned for the following session. To exemplify this procedure further, the lines that follow describe a sample class set up according to the principles described above.

During a lesson on sports and national athletes (see appendix 2), I had participants recognize main ideas and supporting details from a written text through techniques such as skimming, scanning, previewing, and summarizing. I started the class by asking students to brainstorm sports they had been studying throughout the year, or which they had learned elsewhere. I wrote the list down on the board and provided feedback on pronunciation and meaning. Next, I gave an overview of available reading strategies which students had studied previously in the academic year. I explained that scanning was useful in locating dates, years, quantities, and so forth. I also compared scanning in reading with the visual graph displayed in a computer when a document is being scanned. After that, I explained that skimming was useful when locating main ideas, and that a recommendation was to skim for the first and last sentences in a paragraph in order to get a general sense of its content. I then pointed out that typographical and paratextual clues such as font type and size, graphs and accompanying images could tell a lot about the content of a text (previewing). Finally, I commented that summarizing the essence of paragraphs on the margins or on a separate sheet of paper was useful as a way to double check on gist comprehension. Once these strategies had been presented, a crossword puzzle containing target vocabulary was handed out for students to solve collaboratively (in pairs or small groups). All of this was done during the pre-reading cycle.

In the while-reading cycle, once students had previewed the text for typographical and paratextual clues, they were asked to read the comprehension questions in order to get ready for actual reading. Pupils were instructed to pay attention to headings and subheadings as they read so as to prompt reading for inferences and the confirming of such inferences. They were asked to bear in mind the reading strategies reviewed depending on the type of information requested (whether main ideas or details), and they were encouraged to summarize main ideas whenever possible. As they worked on the activity, I took field notes and circulated around, offering help with vocabulary, structures, and ways to better figure out meaning from context. Once they completed the exercises, they were requested to confirm their answer choices by rereading the text for response accuracy. Finally, they were asked to pair up and compare answers with a classmate, discussing vocabulary and/or structures learned, and reflecting on the usefulness of the reading strategies and the crossword puzzle. 
I then went on to check the answers with the class and opened another reading cycle using a text about Hanna Gabriels, another national sports figure.

In the post-reading stage, students reflected orally on their progress and provided suggestions for methodological improvement. After that, they completed a word search activity on vocabulary studied from the two reading activities. Again, I circulated around, assisting them, and taking notes whenever possible. The class ended with the assignment of cooperative homework using a website which will be described next in section 3.3.3. By setting up classroom dynamics like this, I helped create a sense of continuity and dependability of topics and structures throughout the 20 texts we read in the five weeks of the project.

\subsubsection{Arranging tasks following a pre-, while-, and post-reading Cycle}

All classes were arranged following a similar format to the one described in the previous section. Thus, in the pre-reading stage, I provided the students with background vocabulary about the materials they were about to read. I also did other schema activation exercises such as asking open questions to about the focus of the previous class, providing context for what they were about to read, viewing photos and graphs, and pre-reading headings and the questions to be answered before they got to read the texts. In the while-reading stage, I had the students develop their linguistic and schematic knowledge by encouraging them to interact with the text through strategies such as verifying predictions, keeping an eye on information may answer the questions they needed to answer, paying attention to key words, recognizing discourse markers, watching out for context clues such as the use of synonyms, antonyms and exemplifications, and so on. In the post-reading stage, I had them do any of these three things: a) Peer-check their answers with a classmate to socialize progress, b) revisit data to answer questions they did not answer correctly, and/or c) reflect on the reading experience so that weaknesses and strengths in completing the exercises were verbalized. In this stage, as reflection is an important part of all learning, I allowed them to use their mother tongue if they wanted.

\subsubsection{Assigning Collaborative Homework}

In order to ensure follow-up on reading skills, as well as progress awareness, I encouraged the students to solve diagnostic reading exercises from the web site http://thinkinenglishnow.net/?reloaded=true, powered by the Ministry of Public Education and 
available to anyone interested in practicing reading comprehension skills for the ENEE. I encouraged them to take these diagnostic tests in pairs and collaboratively, so that they could do both: Test themselves on their own progress and help each other with unknown vocabulary and structures. At the beginning of every class, I asked them whether they had taken any of these tests and encouraged them to take them if they said they had not. The task was collaterally an opportunity to reinforce recently studied vocabulary and grammar.

\subsection{Instruments}

One artifact and two instruments were used in all of the stages of this action research. The artifact consisted of a Classwork Annotations Sheet on Students' Attitudes and Behaviors, which I had been using non-purportedly since the beginning of the academic year. This instrument was a useful resource in the planning of the action plan because it allowed me to realize that a key problem affecting the students' reading comprehension performance was their lack of basic vocabulary and grammar structures, as well as a generalized negative attitude towards the English subject. The instrument included a space for qualitative annotations which later turned out useful in deciding what kind of action plan was required to meet the students' educational needs. Given its nature, this instrument did not yield data for actual analysis of results.

The second instrument was the Classroom Field Notes, where I recorded evidence of the application of schema theory and scaffolded reading comprehension as systematized in the pre-, while-, and post-reading comprehension stages. It was used both, during and after class. During class, especially in the while-reading stage, this instrument served as a way to collect data and to provide feedback to students after the post-reading stage. When used after class, I resorted to introspective techniques (e.g., recalling major events right after class). While I was aware of the potential for subjectivity in this technique, I was also aware of its potential for methodological triangulation and thus decided to profit from it in the data collection process. As such, this instrument yielded qualitative information that was used to further cross-check the numerical data gathered via the administration of the sample ENEES.

The third instrument was two sample ENEES which I used to assess the students' progress throughout the implementation of the action plan. One of the exams was taken from the textbook English Made Easy: Bachillerato; the second one was taken from the official web site of the MEP's English Regional Advisory Department. They were administered in the middle and at the end of the action plan, respectively. Results from these tests became the 
main source of analysis for this research, for they provided numerical data that indicated the students' progress in terms of test performance, as well as a basis for performance predictability in the actual ENEE.

\subsection{Data Analysis Techniques}

For purposes of clarity, the data analysis will be presented in two sections: a) Numerical results of the first sample ENEE, and b) a numerical analysis of the scores obtained in the second exam; both of them accompanied by tables and verbal explanations of the numerical data. Additionally, test scores for the two sample exams will be grouped as the highest third, the middle third, and the lowest third, where test scores between 70 and 100 will be grouped as the highest third, tests between 60 and 69 will be classified as the middle third, and tests below 60 will be labeled as the lowest third. These thirds will also be analyzed in relation to the students' Grade Point Average (henceforth, GPA).

\section{Results and Analysis}

As stated elsewhere in this paper, the goal of this research was to explore the connection between a small-scale intensive reading comprehension project and students' performance on two sample ENEEs. The lines that follow details the results obtained in the two sample ENEEs. The participants' real identities have been replaced with fictional first names in order to account for confidentiality.

\subsection{Analysis of the Scores in the First Exam}

\subsubsection{Analysis of the Highest Third}

In the lines that follow, tables containing numerical data will be displayed and accompanied by verbal descriptions on the different phenomena investigated.

Upon administration of the first sample test, only one student (Cristina) scored higher than 70 . As table 1 below shows, her raw score was 82.5 , for a $49.7 \%$ out of the total $60 \%$ value of the test. If we take into consideration her GPA (37.97 out of $40 \%$ ), we can predict that this student's final score in the ENEE will be 87.65 , with increase or decrease possibilities depending on internal and external test taking factors such as item difficulty, degree of item discrimination, anxiety, tiredness and/or boredom. The numerical details for the highest third are displayed in the table below. 
Table 1: The Highest Third (Test Scores Between 70 and 100)

Student's Name

Cristina

Source: Researcher's own design

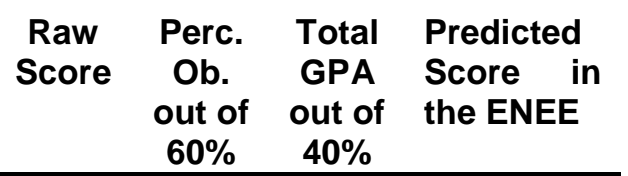

82.5

87.65

\subsubsection{Analysis of the Middle Third}

As table 2 below indicates, the middle third for the first sample test was comprised by a total of six students. While none of the students scored the minimum passing grade (70), in almost all the cases their GPA is high enough as to allow them to pass the ENEE. From this data, we can infer that the only student who would not be passing the ENEE is the first one in the table, Irene. There, we see that her GPA is not very high, which means she did not achieve high in most subjects during tenth and eleventh grade. The case of this student can be further corroborated on analyzing my qualitative annotations during classroom field note 1 , where I wrote: "Irene and Maybel say they need more vocabulary. They say their GPA is low", and during classroom field note 3, in which I recorded: "Irene and Maybel are still very teacher-dependent. They are always sitting by my desk, asking vocabulary questions. They are very hardworking, but very dependent".

In sharp contrast with this participant's case, there is the case of Sheiris. Here, we can see that her grade in this sample test was about the same as Irene's, but her GPA is significantly better, which means she would be passing the ENEE. It is also important to bear in mind that while we can predict that almost all the participants in this third are likely to pass the ENEE, they would be passing with the aid of their GPAs, and that they are in a relatively risky position because most of them would be obtaining grades that are too close to 70 , the minimum passing grade. Table 2 below depicts the numerical data discussed in the preceding lines. 
Table 2: The Middle Third (Test Scores Between 60 and 69)

\section{Student's Name}

\begin{tabular}{|c|c|c|c|}
\hline $\begin{array}{l}\text { Raw } \\
\text { Score }\end{array}$ & $\begin{array}{l}\text { Perc. } \\
\text { Ob. } \\
\text { out of } \\
60 \%\end{array}$ & $\begin{array}{c}\text { Total } \\
\text { GPA } \\
\text { out of } \\
40 \%\end{array}$ & $\begin{array}{l}\text { Predicted } \\
\text { Score in } \\
\text { the ENEE }\end{array}$ \\
\hline
\end{tabular}

\begin{tabular}{l|c|c|c|c}
\hline \hline Irene & 60 & 36 & 32.33 & 68.33 \\
\hline Maybel & 62.85 & 37.7 & 33.67 & 71.3 \\
\hline Sheiris & 62.85 & 37.71 & 35.03 & 72.74 \\
\hline Yerlyn & 64.28 & 38.57 & 36.28 & 74.85 \\
\hline Carlos Josué & 68.57 & 41.14 & 30.08 & 71.22 \\
\hline Jackson & 67.14 & 40.28 & 33.08 & 73.36 \\
\hline
\end{tabular}

Source: Researcher's own design

\subsubsection{Analysis of the Lowest Third}

As for the lowest third, comprised by a total of five students, the highest score was 58.57; while the lowest was 52.85. The student with the lowest grade was Brayan, who, according to my yearly classroom annotations, showed problems with vocabulary and basic structures from the beginning of the school year. As I was able to record during classroom field note 3, "Brayan is very dependent on the dictionary. He is very quiet and hardworking; looks concentrated. Today he asked for the meaning of the word 'kind'." From the numerical data depicted on table 3 below, we can also see that none of these students would be passing the ENEE if their grades do not experience a significant escalation. A pattern that deserves our attention here is that their GPAs are by far lower than that of the other students, which means that their performance in this sample test may not have been the only occasion where they performed low. In other words, their low scores in the sample ENEE correlate with their low scores in their GPAs. This, in turn, suggests a good degree of predictive validity of the GPA scores in relation to national test achievement.

Table 3: The Lowest Third (Test Scores Below 60)

\section{Student's Name}

\begin{tabular}{|c|c|c|c|}
\hline $\begin{array}{l}\text { Raw } \\
\text { Score }\end{array}$ & $\begin{array}{c}\text { Perc. } \\
\text { Ob. } \\
\text { out of } \\
60 \%\end{array}$ & $\begin{array}{c}\text { Total } \\
\text { GPA } \\
\text { out of } \\
40 \%\end{array}$ & $\begin{array}{l}\text { Predicted } \\
\text { Score in } \\
\text { the ENEE }\end{array}$ \\
\hline
\end{tabular}

\begin{tabular}{l|c|c|c|c}
\hline \hline Brayan & 52.85 & 31.71 & 31.44 & 63.15 \\
\hline Fabiana & 54.28 & 32.57 & 30.97 & 63.54 \\
\hline Rebeca Andrea & 55.71 & 33.42 & 31.10 & 64.52 \\
\hline Harry Josué & 57.14 & 34.28 & 34.21 & 68.49 \\
\hline Jairo Antonio & 58.57 & 35.14 & 32.47 & 67.61 \\
\hline
\end{tabular}

Source: Researcher's own design 
Taken together, the total scores obtained in the sample ENEE indicate that, out of the twelve students who took this test, six of them would not be passing the actual ENEE. They also indicate that, as suggested above, students' GPA grades correlate to a high degree with the scores they got in this test. Table 4 below summaries the numerical data discussed for the first part of this data analysis.

Table 4: General Test Scores for the First ENEE

\begin{tabular}{|c|c|c|c|c|}
\hline Student's Name & $\begin{array}{l}\text { Raw } \\
\text { Score }\end{array}$ & $\begin{array}{c}\text { Perc. } \\
\text { Ob. } \\
\text { out of } \\
60 \%\end{array}$ & $\begin{array}{c}\text { Total } \\
\text { GPA } \\
\text { out of } \\
40 \%\end{array}$ & $\begin{array}{l}\text { Predicted } \\
\text { Score in } \\
\text { the ENEE }\end{array}$ \\
\hline Brayan & 52.85 & 31.71 & 31.44 & 63.15 \\
\hline Fabiana & 54.28 & 32.57 & 30.97 & 63.54 \\
\hline Rebeca Andrea & 55.71 & 33.42 & 31.10 & 64.52 \\
\hline Harry Josué & 57.14 & 34.28 & 34.21 & 68.49 \\
\hline Jairo Antonio & 58.57 & 35.14 & 32.47 & 67.61 \\
\hline Irene & 60 & 36 & 32.33 & 68.33 \\
\hline Maybel & 62.85 & 37.7 & 33.67 & 71.3 \\
\hline Sheiris & 62.85 & 37.71 & 35.03 & 72.74 \\
\hline Yerlyn & 64.28 & 38.57 & 36.28 & 74.85 \\
\hline Jackson & 67.14 & 40.28 & 33.08 & 73.36 \\
\hline Carlos Josué & 68.57 & 41.14 & 30.08 & 71.22 \\
\hline Cristina & 82.5 & 49.7 & 37.94 & 87.65 \\
\hline
\end{tabular}

Source: Researcher's own design

\subsection{Analysis of the Scores in the Second Exam}

Upon application of the first sample ENEE, I continued to scaffold the gap between students' actual scores and the desired outcome in the ENEE. Three weeks after the application of the first ENEE, I administered a second sample test, whose scores were as follows.

\subsubsection{Analysis of the Highest Third}

This second time around, a total of three students were able to obtain grades above the minimum passing grade. As we can see from table 5 below, besides Cristina, Jackson and Sheiris were also able to score above 70 . In the three cases, we see significant escalations as compared to the first sample ENEE. Cristina, for example, went from 82.5 to 87.14 ; Jackson went from 67.14 to 71.42 ; while Sheiris went from 62.85 to 74.28 . In my classroom field notes I collected during classroom observations, during the pre-reading stage, when I 
asked them if they had done online practice tests, Sheiris responded that she did not have time to do a complete test because she was studying for biology, but that she had done part of it with Cristina and that she sees progress in her reading skills. On the whole, we can see that in about three weeks of intensive reading comprehension, there is an important evolution in terms of test scores, which are summarized in table 5 below.

Table 5: The Highest Third (Test Scores Between 70 and 100)

\begin{tabular}{|c|c|c|c|c|}
\hline Student's Name & $\begin{array}{l}\text { Raw } \\
\text { Score }\end{array}$ & $\begin{array}{c}\text { Perc. } \\
\text { Ob. } \\
\text { out of } \\
60 \%\end{array}$ & $\begin{array}{c}\text { Total } \\
\text { GPA } \\
\text { out of } \\
40 \%\end{array}$ & $\begin{array}{l}\text { Predicted } \\
\text { Score in } \\
\text { the ENEE }\end{array}$ \\
\hline Jackson & 71.42 & 42.85 & 33.08 & 75.93 \\
\hline Sheiris & 74.28 & 44.57 & 33.08 & 77.65 \\
\hline Cristina & 87.14 & 52.28 & 37.94 & 90.22 \\
\hline
\end{tabular}

Source: Researcher's own design

\subsubsection{Analysis of the Middle Third}

This third is now made up of seven students, as opposed to six in the first ENEE. In almost all the cases, there are important improvements with regard to the first test, but there are two cases that call for special attention here. In the first place, it is important to note that the student Maybel experienced a decrease in test scores. While in the first test she obtained a raw score of 62.85 , her raw score in the second test was 61.42 . This is particularly significant because, as I was able to record in my field notes, this student was very hardworking and committed. She never missed any of the reinforcement classes and she reported to always be in touch with the language. A hunch on the reasons for her decrease can be explained in field notes 1 and 3, where I record that she and her sister, Irene, struggled a lot with vocabulary, and that they needed a great deal of additional reinforcement. In the second place is the case of Rebeca, who, despite her test score improvement in the second ENEE (60 as opposed to 55.71 in the first one), would still not be passing the real ENEE. Predictably, if she obtains a 60 in the actual ENEE, her total score (considering her GPA) would be 67.10 , an immediate failing grade. This means that while she improved her score in the second sample test, her low achievement adds up to the claim I made before that, in most cases, the low scores in the students' GPA is a good predictor of the scores they may get in the ENEEs. Table 6 displays the numerical data discussed for the middle third. 
Table 6: The Middle Third (Test Scores Between 60 and 69)

\section{Student's Name}

\begin{tabular}{|c|c|c|c|}
\hline $\begin{array}{l}\text { Raw } \\
\text { Score }\end{array}$ & $\begin{array}{c}\text { Perc. } \\
\text { Ob. } \\
\text { out of } \\
60 \%\end{array}$ & $\begin{array}{c}\text { Total } \\
\text { GPA } \\
\text { out of } \\
40 \%\end{array}$ & $\begin{array}{l}\text { Predicted } \\
\text { Score in } \\
\text { the ENEE }\end{array}$ \\
\hline
\end{tabular}

\begin{tabular}{l|c|c|c|c}
\hline \hline Rebeca Andrea & 60 & 36 & 31.10 & 67.1 \\
\hline Maybel & 61.42 & 36.85 & 33.67 & 70.52 \\
\hline Jairo Antonio & 62.85 & 37.71 & 32.47 & 70.18 \\
\hline Irene & 64.28 & 38.57 & 32.33 & 70.90 \\
\hline Harry Josué & 64.28 & 38.57 & 34.21 & 72.75 \\
\hline Fabiana & 64.28 & 38.57 & 30.97 & 69.54 \\
\hline Yerlyn & 68.57 & 41.14 & 36.28 & 77.42 \\
\hline
\end{tabular}

Source: Researcher's own design

\subsubsection{Analysis of the Lowest Third}

In the case of the lowest third, one student (Brayan) scored below 60, just as he did in the first sample ENEE. We also see that another student (Carlos, no show) was placed in the lowest third because he did not attend class on the day the second sample ENEE was administered. In the case of Brayan, improvement is recorded in comparison with the score he got in the first sample test (52.85). Still, he scored below the minimum passing grade, and was not able to score a minimum passing grade even if adding his total GPA. This case merits our attention because as reported during classroom observation 6, "Brayan [and Jackson] said they had done a complete test together and that their grades were improving". In the future, it would be enriching to find out in more detail why, despite the effort he places on the subject, this participant was not being able to comprehend texts in English successfully. Table 7 exhibits the full range of numerical data for the lowest third.

Table 7: The Lowest Third (Test Scores Below 60)

\begin{tabular}{|c|c|c|c|c|}
\hline Student's Name & $\begin{array}{l}\text { Raw } \\
\text { Score }\end{array}$ & $\begin{array}{c}\text { Perc. } \\
\text { Ob. } \\
\text { out of } \\
60 \%\end{array}$ & $\begin{array}{c}\text { Total } \\
\text { GPA } \\
\text { out of } \\
40 \%\end{array}$ & $\begin{array}{l}\text { Predicted } \\
\text { Score in } \\
\text { the ENEE }\end{array}$ \\
\hline Carlos Josué & $\begin{array}{c}\text { No } \\
\text { Show }\end{array}$ & $\begin{array}{c}\text { No } \\
\text { Show }\end{array}$ & 30,08 & 30.08 \\
\hline Brayan & 58.57 & 35.14 & 31.44 & 66.58 \\
\hline
\end{tabular}

Source: Researcher's own design

In general, data from students' scores in the two sample ENEEs, as well as from the classroom field notes, suggests fair degrees of improvement from sample ENEE 1 to sample ENEE 2, as shown in table 8 below. 
Table 8: General Test Scores for the Second ENEE

Student's Name

Raw Perc. Total Predicted

Score Ob. GPA Score in out of out of the ENEE $60 \% \quad 40 \%$

\begin{tabular}{l|c|c|c|c}
\hline \hline Carlos Josué & NS & NS & 30.08 & 30.08 \\
\hline Brayan & 58.57 & 35.14 & 31.44 & 66.58 \\
\hline Rebeca Andrea & 60 & 36 & 31.10 & 67.1 \\
\hline Maybel & 61.42 & 36.85 & 33.67 & 70.52 \\
\hline Jairo Antonio & 62.85 & 37.71 & 32.47 & 70.18 \\
\hline Fabiana & 64.28 & 38.57 & 30.97 & 69.54 \\
\hline Irene & 64.28 & 38.57 & 32.33 & 70.90 \\
\hline Harry Josué & 64.28 & 38.57 & 34.21 & 72.75 \\
\hline Yerlyn & 68.57 & 41.14 & 36.28 & 77.42 \\
\hline Jackson & 71.42 & 42.85 & 33.08 & 75.93 \\
\hline Sheiris & 74.28 & 44.57 & 33.08 & 77.65 \\
\hline Cristina & 87.14 & 52.28 & 37.94 & 90.22 \\
\hline
\end{tabular}

Source: Researcher's own design

For a broader picture on the numerical escalations of the twelve participants, table 9 below depicts the numbers discussed in this section. In the first column to the right of the student's name, the raw scores for the first sample ENEE are shown, followed by the total percentage gotten. The third column depicts the predicted ENEE score resulting from adding student's raw ENEE scores to their corresponding GPA scores. The last three columns on the right contain this same information but for the second sample ENEE.

Table 9: Comparison of Results between the Two Sample ENEEs

\begin{tabular}{|c|c|c|c|c|c|c|}
\hline Student's Name & $\begin{array}{c}\text { Sample } \\
\text { Test } N^{\circ} 1 \\
\text { (Raw } \\
\text { Score) }\end{array}$ & $\begin{array}{l}\text { Test } \\
\mathrm{N}^{\circ} 1 \\
(\%)\end{array}$ & $\begin{array}{l}\text { Predicted } \\
\text { Score in } \\
\text { the ENEE }\end{array}$ & $\begin{array}{c}\text { Sample } \\
\text { Test N² } \\
\text { (Raw } \\
\text { Score) }\end{array}$ & $\begin{array}{l}\text { Test } \\
N^{\circ} 2 \\
(\%)\end{array}$ & $\begin{array}{l}\text { Predicted } \\
\text { Score in } \\
\text { the ENEE }\end{array}$ \\
\hline Brayan & 52.85 & 31.71 & 63.15 & 58.57 & 35.14 & 66.58 \\
\hline Fabiana & 54.28 & 32.57 & 63.54 & 64.28 & 38.57 & 69.54 \\
\hline Rebeca Andrea & 55.71 & 33.42 & 64.52 & 60 & 36 & 67.1 \\
\hline Harry Josué & 57.14 & 34.28 & 68.49 & 64.28 & 38.57 & 72.75 \\
\hline Jairo Antonio & 58.57 & 35.14 & 67.61 & 62.85 & 37.71 & 70.18 \\
\hline Irene & 60 & 36 & 68.33 & 64.28 & 38.57 & 70.90 \\
\hline Maybel & 62.85 & 37.7 & 71.3 & 61.42 & 36.85 & 70.52 \\
\hline Sheiris & 62.85 & 37.71 & 72.74 & 74.28 & 44.57 & 77.65 \\
\hline Yerlyn & 64.28 & 38.57 & 74.85 & 68.57 & 41.14 & 77.42 \\
\hline Jackson & 67.14 & 40.28 & 73.36 & 71.42 & 42.85 & 75.93 \\
\hline Carlos Josué & 68.57 & 41.14 & 71.22 & NS & NS & 30.08 \\
\hline Cristina & 82.5 & 49.7 & 87.65 & 87.14 & 52.28 & 90.22 \\
\hline
\end{tabular}

Source: Researcher's own design 


\section{Conclusions, Limitations, and Further Research}

Upon completion of this action research, two central conclusions have been drawn. The first one is that findings suggest a relation between small-scale intensive reading comprehension and students' performance in sample ENEEs. This allows us to speculate that scaffolded intensive reading comprehension positively impacts students' performance in sample ENEEs. As table 9 in the previous section shows, test scores suggest general degrees of escalation from sample test 1 to sample test 2 . If we bear the specifics of the context where the study took place, these numbers are quite an achievement since improvement was achieved in a short period of time. Preliminary speculation is that such escalations have to do with the fact that the readings were scaffolded to help the students integrate previously existing background knowledge with newly incoming data. This initial success may also be linked to the fact that students were assigned collaborative homework where they had the chance to take similar sample tests on their own with the aid of their peers. This, as documented in the classroom field notes, gave the students a sense of achievement and confidence that may have impacted test scores positively.

The second conclusion is that while scaffolded reading comprehension comprises an alternative to attend to the issue of reading comprehension in our public education settings, we must be aware that some students may need more scaffolding in the processing of the reading material. This was particularly evident in the case of one student, who, in both cases, was ranked in the lowest third presumably because of lack of vocabulary and overall language skills. This implies that the action plan implemented is affective but only insofar as the students are within the Zone of Proximal Development necessary to process newly incoming data. Future research should take this into consideration so that better scaffolding is devised as a way to help all the students bridge the gaps between their reading comprehension competence levels and the desired outcome as set by the MEP.

Alternatively, we could also venture to conclude that while scaffolded reading comprehension has proven effective for the context of this study, we must also consider variables such as the probability that poor reading proficiency is not necessarily the result of poor scaffolding, but perhaps the product of other individual needs. This would in turn imply that, besides scaffolding, teachers and curricular authorities need to seek the means to attend to such individual needs, and that research would also need to be conducted along these lines. 
Taken together, however, findings up to now suggest that action research projects such as the one implemented herein offer an alternative to solve everyday teaching problems in the context of foreign language education. Nonetheless, there are a number of limitations that must be considered for further research.

First, caution is advised with the interpretation of findings as these are not transferrable to larger populations because the sample used was a small one. Second, since the study was limited to assessing test performance only, a number of important socio-affective factors such as personality, student preferences and motivation, self-esteem, etc. and their incidence in test scores were left unexplored. Lastly, it was not possible to assess the amount and quality of students' out-of-class preparation during the conduction of the action research plan. Therefore, it is uncertain whether the results reported are $100 \%$ the product of the students' immersion in the action plan or the result of some additional preparation afforded by their own means. Given these limitations, I am aware that only more research will help us arrive at more solid conclusions on they how scaffolded intensive reading comprehension techniques impact test scores.

Future research should address these and similar issues so that more conclusive evidence can be reached. In the meantime, this small-scale research has opened an avenue for reflection, improved pedagogical practice, and further exploration of the effect of scaffolded reading comprehension on students' ENEE performance.

\section{References}

Acuña, Elian, and Campos, Rodrigo. (October, 2015). Interactive Reding: $A$ Method to Enhance EFL Learners' Reading Habits. Proceedings of the II Congreso de Lingüística Aplicada CONLAUNA, Pérez Zeledón, Costa Rica.

Alyousef, Hesham Suleiman. (2005). Teaching Reading Comprehension to ESL/EFL Learners. The Reading Matrix, 5(2), 143-154.

Anders, Patricia. (2002). Toward an Understanding of the Development of Reading Comprehension Instruction Across the Grade Levels. In C.M. Roller (Ed.), A Collection of Papers from the Reading Research 2001 Conference (pp. 111-132). Chicago, IL: International Reading Association, Inc.

Attarzadeh, Mohammad. (2011). The effect of Scaffolding on Reading Comprehension of Various Text Modes on Iranian EFL Learners with Different Proficiency Levels. Scientific International Journal, 8(2), 4-29.

Bula, Olmedo. (2015). Action Research: Fostering Students' Oral Production in the EFL Class. Revista de Lenguas Modernas, (23), 349-363. 
Bula, Olmedo. (2010). The Use of Recast in the EFL Classroom through Action Research Approach. Revista de Lenguas Modernas, (13), 225-240.

Coon, Megon, Ferrell, Ken, and Kevin Klott. (2014). English Bachillerato Prep Course. A Guide to Preparing Students for the Ministry of Public Education's Graduation Exam. Retrieved from http://www.liceodepoas.ed.cr/uploads/4/3/0/4/43041915/bachillerato prep peace corps .pdf

Choo, Tan Ooi Leng, Eng, Tan Kok, and Ahmad, Norlida. (2011). Effects of Reciprocal Teaching Strategies on Reading Comprehension. The Reading Matrix 11(2), 140-149. Retrieved from http://www.readingmatrix.com/articles/april 2011/choo eng ahmad.pdf

Córdoba, Patricia, Coto, Rossina and Marlene Ramírez. (2005). La enseñanza del inglés en Costa Rica y la destreza auditiva en el aula desde una perspectiva histórica. Revista Actualidades Investigativas en Educación, 5(2), 1-12. Retrieved from http://revista.inie.ucr.ac.cr/index.php/aie/article/view/71

Derry, Sharon. (1996). Cognitive Schema Theory in the Constructivist Debate. Educational Psychologist, 31(3/4), 163-174.

Díaz-Ducca, Jenaro. (2015). Working with Documentaries in the EFL Classroom: Successful Strategies for Decreasing Anxiety during Oral Tests. Revista de Lenguas Modernas, (23), 235-252.

Ebrahimi, Nabi, and Rahimi, Ali. (2013). Towards a more efficient EFL reading comprehension classroom environment: The role of content and critical reading. Apples - Journal of Applied Studies, 7(2), 1-15.

Efron, Sara, and Ravid, Ruth. (2013). Action Research in Education: A Practical Guide. New York: Guilford Publications.

Erten, İsmail, and Razi, Salim. (2009). The effects of cultural familiarity on reading comprehension. Reading in a Foreign Language, 21(1), 60-77.

Font, Alberto. (June 02, 2014). Costa Rica's month-long teachers' strike comes to an end. The Tico Times. Retrieved from: http://www.ticotimes.net/2014/06/02/costa-ricasmonth-long-teachers-strike-comes-to-an-end

Latorre, Antonio. (2014). La investigación-acción: Conocer y cambiar la práctica educativa. Barcelona, España: Editorial Graó.

McLaughlin, Maureen, and Overturf, Brenda. (2013). The Common Core: Teaching Students in Grades 6-12 to Meet the Reading Standards. Newark, DE: International Reading Association.

Ministerio de Educación Pública (MEP), Costa Rica. (2014). English Syllabus for Diversified Education. San José, Costa Rica: MEP. 
Novotny, Kathryn. (2011). Reading Comprehension in the Secondary Classroom (In partial fulfillment of the requirements for the degree of Master of Science in Reading). Minnesota State University, Mankato, USA.

Otárola, Cindy, and Valverde, Marigen. (2013). Nurturing Literacy Development throught Constructivist Strategies in EFL Sixth Graders: The Case of Villareal School (Tesis para optar por el grado de licenciatura en Ciencias de la Educación con Énfasis en la Enseñanza del Inglés para I y II Ciclo). Universidad Estatal a Distancia, San José, Costa Rica.

Ramírez, Jimmy. (2013). English Made Easy: Bachillerato. San José, Costa Rica: Grupo Dinatext S.A.

Rhea, Anisa, and Nancy Baenen. (2007). Project IRIS: intensive reading intervention study, a three-year follow-up. Retrieved from https://webarchive.wcpss.net/results/reports/2007/0620proj iris followup.pdf

Richards, Jack, and Lockhart, Charles. (1994). Reflective Teaching in Second Language Classrooms. Cambridge, England: Cambridge University Press.

Roberts, Amy. (1999). Taming the monsters: practical intimacies in a third grade costa rican classroom. In Educational Action Research, 7(3) 345-363. DOI: 10.1080/09650799900200093

Sevilla, Henry and Gamboa, Roy. (October, 2015). Student Self-evaluation and Autonomy Development in EFL Learning. Proceedings of the II Congreso de Linguística Aplicada CONLAUNA, Pérez Zeledón, Costa Rica.

Shen, Yanxia. (2008). An Exploration of Schema Theory in Intensive Reading. English Language Teaching, 1(2), 104-107.

Trinity Western University Counseling Center. (n.d.). Intensive Reading Techniques. Retrieved from http://www.twu.edu/downloads/counseling/A-

7 Intensive Reading Technique.pdf

Willis, Arlette. (2014). Reading Comprehension Research and Testing in the U.S.: Undercurrents of Race, Class, and Power in the Struggle for Meaning. New York: Lawrence Erlbaum Associates.

Zainuddin, Hanizah, Yahya, Noorchaya, Morales-Jones, Carmen and Ariza, Eileen. (2011). Fundamentals of Teaching English to Speakers of Other Languages in K-12 Mainstream Classrooms. Dubuque, lowa: Kendall Hunt Publishing Co. 


\section{Appendices}

Appendix 1: Classroom Field Notes

Observation № I Date: / Time: I №

\section{A. The Pre-reading Stage} of Students ___ Place:

Teacher's elicitation of background knowledge, topic overview, planning, and other pre-reading techniques

Students' responses to elicitation

\section{B. The While-reading Stage:}

Students' decoding of meaning through summaries, mind maps, inferences, meaning guessing, re-reading, and other while-reading techniques

Completion of while-reading tasks

\section{The Post-reading Stage:}

Students' reflection on the experience 
Students' success in wrap-up activities such as double-checking on an answer, matching, and whole-class comprehension questions

GENERAL COMMENTS ABOUT THE CLASS 


\section{Appendix 2: Sample Lesson Plan}

Topic: Sports and National Athletes

Objective: Recognize the gist and specific details in a text about sports and national athletes

\section{Strategies:}

- Skimming

- Scanning

- Previewing

- Summarizing

Materials: A crossword puzzle, the book English Made Easy: Bachillerato, an additional text on Hanna Gabriels, and a word search on sports and national athletes.

\section{Procedures:}

\section{The Pre-reading Stage}

- T elicits background knowledge by providing a topic overview. T asks Ss to brainstorm some of the sports they studied throughout the course of the year. T provides feedback.

- T discusses reading strategies and some tips to discard items in the NEEE.

- Ss solve a crossword puzzle on Sports and Leisure Activities

\section{The While-reading Stage:}

- Ss read the questions first and check for understanding

- Ss read headings and subheadings to infer content of the text, thinking about what they know about the title, about the first paragraph, etc. They are encouraged to pay attention to opening and closing paragraphs. They should read along and be able to get the gist.

- They go back into the text and try to verify the answers they chose or change them (rereading) if necessary. They are encouraged to peer-check their answers and to give each other feedback.

- Ss repeat this same procedure with the text about Hanna Gabriels.

\section{The Post-reading Stage:}

- Students' reflection on the experience 
- Students do wrap-up activity: Word search. They peer-check their answers and are allowed to make additional comments.

- Cooperative homework is assigned. Visit the web page http://thinkinenglishnow.net/?reloaded=true and solve sample tests cooperatively, helping each other. 